\title{
Evaluation of the resistance to insecticides in Aedes aegypti, transmitter of dengue, in Latin America
}

\author{
Evaluación de la resistencia a insecticidas en Aedes aegypti, transmisor de dengue, en América \\ Latina
}

\author{
Amparo G. Hernández Ramos ${ }^{a}$
}

\begin{abstract}
:
Dengue is an infectious disease with high rates of morbidity and mortality, transmitted by the bite of the female mosquito of the genus Aedes aegypti, vector distributed in tropical and subtropical areas throughout the world. America is one of the most affected regions. This vector is controlled through insecticides that due to its constant use in populations, a resistance phenomenon has been produced. The objective of this review is to identify the situation of insecticide resistance in populations of Aedes aegypti in Latin American countries. In this region, several insecticides have been used for vector control; in the last 10 years insecticides of the pyrethroid and organophosphorus group have been used as adulticides for the control of the mosquito, conditioning resistance. Some insecticides such as organophosphates and deltamethrin, despite of not being intensively used in Latin American countries, also show resistance. Improvements in vector control are required, including the rotation of the insecticides during the different seasons, as well as innovating techniques and forms of vector control.
\end{abstract}

Keywords:

Aedes aegypti, resistance, insecticides

Resumen:

El dengue es una enfermedad infecciosa con altas tasas de morbi-mortalidad, transmitida por la picadura de la hembra del mosquito del género Aedes aegypti, vector distribuido en zonas tropicales y subtropicales en todo el mundo, una de las regiones más afectadas es las Américas. El control de dicho vector se realiza mediante la aplicación de insecticidas que por su constante uso en poblaciones han producido el fenómeno de resistencia. El objetivo de esta revisión es identificar la situación de la resistencia a insecticidas en poblaciones de Aedes aegypti en países de América Latina. En esta región se han empleado diversos insecticidas como medios de control vectorial; en los últimos 10 años insecticidas del grupo de piretroides y organofosforados se han empleado para el control del mosquito en su fase adulta, condicionando resistencia. Se ha observado que algunas cepas de mosquitos muestran resistencia ante algunos grupos de insecticidas como los organofosforados y la deltametrina pese a no haber sido empleados intensivamente en países de América Latina. Se requieren mejoras en el control del vector, que incluyan rotación de los insecticidas durante las diferentes temporadas, así como innovar en las técnicas y formas de control de los vectores.

\section{Palabras Clave:}

Aedes aegypti, resistencia, insecticidas

\section{INTRODUCTION}

Dengue is an infectious disease whose symptoms usually appear between 3 and 4 days after infection; it usually affects people at any age; it can present with high fever, headache, retro-ocular pain, myalgias, arthralgias, vomiting, lymphadenopathies that are usually self-limiting. However, it can present in its severe form that is potentially fatal, due to the presence of plasma extravasation, dyspnoea, hemorrhages or organic failure. ${ }^{1}$
This is a disease caused by an RNA virus of the flavivirus genus of the family flaviridae ${ }^{2}$ of which 4 serotypes are known to be transmitted by the bite of the female mosquito, mainly of the genus Aedes aegypti. ${ }^{3}$ This vector is of great importance, since it is also the transmitter of other viral diseases such as yellow fever $^{4}$, zika, chikungunya ${ }^{5}$ and this can occur asymptomatically or in its severe forms; generating high rates of morbidity and mortality in the population. ${ }^{6}$

In recent studies, a new serotype has been identified in the Asian continent, which follows the sylvatic cycle, which can be an

\footnotetext{
a Autor de Correspondencia, Docente Universidad del Futbol y Ciencias del Deporte, Línea de la Salud, Email: dra.gabriela.hera@ gmail.com
} 
indicator of the severity of the disease. ${ }^{5}$ In Southeast Asia, dengue represents more than 1.3 billion cases in the population, equivalent to $52 \%$ of people at risk around the world. One of the largest epidemics with 44,098 cases and 98 deaths happened in Lao in 2013. ${ }^{7}$

The transmission of these diseases occurs mainly in places of tropical and subtropical climate $e^{3,7,8}$ in both urban and semi-urban areas around the world. America is one of the most affected regions ${ }^{9}$, where it is considered one of the most important reemerging diseases. ${ }^{6}$

In the last decade, a high morbidity and mortality associated with dengue has been identified ${ }^{10}$, it has positioned itself as the most important viral disease transmitted by mosquito; epidemics occur every 3 to 5 years, with evidence of increased severity in cases and the magnitude of episodes. ${ }^{11}$ In America, in 2014, 1.1 million cases were reported, of which 16,000 were severe cases and there were 761 deaths. ${ }^{12}$

The economic burden of this disease is high, because it leaves great economic losses every year, most of the costs have to do with indirect costs. It is estimated that in America the cost of attention in dengue cases in the period 2000-2007 increased to 2.1 billion dollars per year. ${ }^{11 / 4}$

The number of cases that is reported is probably lower than the real one, because it can usually be confused with other viral diseases that present with high fever and similar conditions. ${ }^{2}$

The presentation patterns are usually stationary or cyclical; in the latter, every 5 years there are peaks of the disease followed by a decrease in the incidence, and on the other hand the stationary patterns are governed by the rainy seasons. The Aedes aegypti vector is between $35^{\circ}$ North latitude and $35^{\circ}$ South latitude, below 1,200 meters above sea level..$^{3,6}$

Originally the mosquito came from Africa, but has lived in the Caribbean for more than 350 years. It is an insect with complete metamorphosis, since its biological cycle includes 4 stages: egg, larva, pupa, and adult. ${ }^{3}$

\section{AEDES AEGYPTI CONTROL}

It has been observed that the reduction of immature populations has a significant impact on the incidence of diseases in endemic areas; adult control is encouraged especially during periods of epidemics. ${ }^{8}$

The first 25 years of the last century, the activities of control of the mosquito were focused on reducing it, using larvicides based on oily compounds and larvivorous fish and the control of the environment. ${ }^{13,14}$
Later, in the forties, the emergence of dichloro diphenyl trichloroethane (DDT) started the chemical control of the vector as larvicide and adulticide. It is an organochlorine whose use was very broad in the control of pests ${ }^{13}$. However, due to its toxic effects in mammals, persistence in the environment and accumulation in agricultural products, as well as teratogenic and carcinogenic in humans, its use was banned in multiple countries. ${ }^{14}$

In December 2015, the first dengue vaccine called Dengvaxia ${ }^{\circledR}$ was authorized in Mexico for people between 9 and 45 years old, living in endemic areas. It has been authorized in several endemic countries. It is a recombinant tetravalent vaccine in vivo, it consists of 3 doses of application at 0, 6 and 12 months of application. It is still in the experimentation phase and has not shown high effectiveness ${ }^{2}$, so that currently dengue control is carried out mainly with the reduction of population density, the decrease of hatcheries and environmental sanitation programs, with the active participation of the community. ${ }^{15}$

In the same way, biological control with predators of larvae such as small fish called copepods, entomopathogenic bacteria such as Bacillus thuringinesis var israelensis $(\text { Bti })^{16,17}$, endosymbiotic bacteria inherited from mother to offspring, which is stored in weaves avoiding the invasion of other pathogens ${ }^{14}$; and even the use of natural metabolites derived from living organisms, such as spinosad, the metabolite of Saccharopolyspora spinosa, which acts on acetylcholine, nicotinic postsynaptic and gammaaminobutyric receptors. ${ }^{18}$

As a complement, physical control measures such as personal protection are suggested through the use of repellents that are generally derived from pyrethroids a group of insecticides. ${ }^{5}$

The chemical control is carried out with insecticides that act on larvae or adult mosquitoes ${ }^{7}$; the most used in recent decades are divided into 4 groups, all of them neurotoxic: carbamates, organochlorines, organophosphates and pyrethroids. These last two are the most used ${ }^{16}$; that can be applied in larval or adult stages. $^{4}$

The most common applications for larval stages are temephos and fenithion, fenittrothion, pyrethroids and malathion to eliminate adult mosquitoes. Two additional classes of insecticides have recently been made available: spinosyns whose mechanism of action is to modulate the acetylcholine receptors; and insect growth regulators involved in the synthesis of chitin. ${ }^{16}$

\section{RESISTANCE TO INSECTICIDES}

It has been observed that the indiscriminate use of insecticides has resulted in loss of the susceptibility of Aedes aegypti ${ }^{2,8}$, resistance to insecticides according to the United Nations Organization for Agriculture and Food is "the development of 
the ability of a species of insects to tolerate high doses of toxicants, which can be lethal in most individuals of a normal population of the same species", arises as a result of the excessive application of a insecticide ${ }^{3}$ and has become one of the main obstacles for the control of pests ${ }^{5}$, this problem threatens the progress in the elimination and control of vector-borne diseases, in this case dengue. ${ }^{14}$

The first case of insecticide resistance was documented in 1946, in domestic flies to DDT in Denmark and Switzerland. ${ }^{3}$

Some factors such as the climate, growth of urbanization zones without planning, the conditions and quality of life of the population, the low development and vulnerability of the population and the wide distribution of the mosquito, as well as the circulation of the different serotypes, aggravate the problem. ${ }^{19}$

Resistance to insecticides in Aedes species is mainly due to the increase of metabolic detoxification through the enzymatic systems present in the body or by the alteration of the target site $^{11}$, as well as overexpression or genetic amplification of the classes of enzymes such as carboxylesterases (CCE), glutathione S-transferases (GST) and cytochrome P450s (CYP450s) or mixed function oxidases (MFO) have shown resistance to insecticides; it has also been suggested less frequent resistance mechanisms such as resistance for decreased behavior and penetration in the cuticle ${ }^{3,20}$, fundamental implications for vector control and therefore control of the disease..$^{5,21}$

Metabolic resistance is a process that involves the regulation of the detoxification system of mosquitoes. It consists in increasing the activity of enzymes to process the insecticide (it is metabolized before it reaches its target site); the detoxification to the insecticide can be a consequence of the overproduction or the structural modification of an enzyme; however, different enzymes from the same families can act simultaneously to generate resistance. ${ }^{8}$

This phenomenon is a consequence of genetic changes that alter the biochemical processes that occur at the individual level but are visible in a population. Cross resistance occurs when an organism is simultaneously sensitive to different insecticides that have a similar mechanism of action; another type of resistance is known as multiple, an organism is resistant to insecticides with different mechanism of action and does not necessarily imply cross resistance. ${ }^{3}$

Resistance can be detected through susceptibility tests made to insecticides called bioassays that are based on dose-mortality, in which the presence or absence of susceptibility can be identified; however, the mechanism of the resistance can not be known. ${ }^{3}$
These are the gold standard to quantify the resistance to insecticides as well as the cross resistance and make recommendations to use alternative insecticides in a rotation in case of presenting resistance. ${ }^{8}$

The World Insecticide Resistance Network, with the support of the World Health Organization (WHO), was established to track resistance to insecticides in arbovirus vectors and to know the potential deployment of alternatives. ${ }^{10}$

The objective of this review is to identify the situation of insecticide resistance in adult larvae and mosquito populations of Aedes aegypti in Latin American countries.

\section{MEASUREMENT OF RESISTANCE TO INSECTICIDES}

For the identification of resistance to insecticides, the WHO designed a methodology to conduct bioassays, in which it evaluates the susceptibility of mosquitoes exposed to insecticide impregnated paper, at different doses for a specific period of time and subsequently, the mortality of the vectors was observed. A great disadvantage of these kits is their high cost. ${ }^{22,23}$

Based on the need to determine the resistance, the Centers for Disease Control and Prevention (CDC) of Atlanta designed a methodology to determine the resistance of larvae and mosquitoes to insecticides; allowing to know the target site or time of action, which increased in the presence of resistance mechanisms ${ }^{19}$, which is one of the main obstacles for a successful prevention and control of the disease. ${ }^{24}$

For the interpretation of the results, it is indicative of susceptibility to an insecticide a mortality result higher than $98 \%$, between $80 \%$ and $97 \%$ of lethality it is necessary to verify the resistance. Finally, less than $80 \%$ of lethality means high resistance. $^{3}$

\section{MECHANISMS OF RESISTANCE TO INSECTICIDES}

The irrational use of insecticides is capable of causing noticeable effects in the biology of the mosquito, causing changes in its vital functions or in its behavior, giving as a consequence the resistance. $^{3}$

The resistance to pyrethroids is mainly due to the development of intrinsic genetic characteristics that favor the expression of resistance genes. Another phenomenon to which it is attributed is the cross-resistance to organochlorines, because they have the same mechanism of action. ${ }^{6}$

The positive correlation between the activity of detoxificant esterases and the resistance to organophosphates has been demonstrated $^{25}$, acting by sequestering the insecticide before it reaches the cholinesterase site. ${ }^{26}$ 
The resistance to insecticide can give a general cross-resistance against other insecticides that have a similar mechanism of action. $^{3}$

\section{PANORAMA OF RESISTANCE TO INSECTICIDES IN LATIN AMERICAN COUNTRIES}

In recent years, there has been an increase in the incidence of dengue cases associated with the use of insecticides due to the resistance of vectors. ${ }^{6}$

In Latin America, several types of insecticides have been used in vector control, such as DDT, used in Mexico in the year 1960 to control malaria. However, as it was already mentioned, its use was suspended due to its adverse effects, so in 1989 it was replaced by Malathion as an adulticide. In the last 10 years, insecticides from the pyrethroid and organophosphorus groups have been used constantly as adulticides to control Aedes aegypti. ${ }^{3}$

In 2016, two strains were evaluated in a state of Mexico following the CDC methodology, where susceptibility was observed to all insecticides, except for permethrin. ${ }^{22}$

Another study carried out by Bisset Lazcano et al., in 2009, based on the WHO bioassay methodology, showed that from the collected larvae offspring in cities of El Salvador, presented high resistance to temephos, a moderate resistance of the mosquito to pyrethroids: deltametrhin and cypermethrin, and complete susceptibility to lambdacialothrin and chlorpyrifos. At the same time, the resistance mechanisms were investigated, within which it was found that the esterases are associated to temephos resistance, similar to other countries such as Venezuela, Trinidad and Tobago, Cuba, Peru, and Brazil. ${ }^{4}$

In cities of Brazil that is an endemic area of Aedes aegypti, periods of cyclical disease presentation are observed, in the years 1987, 1994, 2001 and 2008, so in the last 13 years pyrethroids and organophosphates have been used as methods of control. ${ }^{16}$

Since 1999, in Sao Paolo, cases of resistance have been reported. In a population called Ceará, in the year 2000, it was reported the resistance to temephos, so to control the vector, the insecticide was replaced by Bacillus thuringiensis israelensis (Bti) between 2003 and 2009 with rotations of insecticides to control larvae, every 3 to 4 years ${ }^{16}$, coinciding with a study by Pereira et al., who observed that in 2 out of 3 municipalities in Brazil there were high levels of resistance to temephos and cypermethrin and in the other population with moderate resistance, alterations in the activity of GST and esterases were

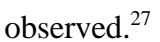

While in cities like Fortaleza, Caucaia and Jazeiro do Norte, Brazil, the continuous use of the insecticide was maintained until the beginning of 2010, when it was observed that the populations were also resistant to malathion. In a population of Brazil, a decrease in the resistance levels was observed after the suspension of an organophosphate and its substitution by Bti. ${ }^{27}$

A study carried out in 12 municipalities of 5 states of Brazil, between 2010 and 2012, where bioassays were conducted under the WHO methodology, all populations showed resistance to temephos and deltamethrin, the latter associated with alterations of union at the diana site. ${ }^{10}$

For many years in Colombia, temephos (organophosphate) was used as a larvicide of a large residual species. Temephos has been used extensively as an adulticide in epidemics since $1980 .{ }^{19}$

In 1988 the first epidemic outbreak occurred in Guayaquil, Ecuador, the insecticide used was temephos as larval control. ${ }^{28}$

Guayaquil, is a highly urbanized area in Ecuador and is the province with more cases at the national level, so a resistance evaluation of 2 strains was carried out. One of them presented susceptibility to temephos and with greater larvicidal and pupicidal action; while the other strain expressed moderate resistance to the same insecticide, with lower larvicidal activity and limited action in adult populations. ${ }^{28}$

In Cuba, like other countries, temephos is also frequently used in the control of larvae and the use of pyrethroids in the case of adult mosquitoes in epidemic situations. ${ }^{29}$

In a study carried out with 5 strains, 4 of them Venezuelan and one strain from Santiago de Cuba, it was used the WHO methodology. The results revealed that 3 of the 4 Venezuelan strains were resistant to pirimiphos-methyl; in comparison to the strain from Santiago de Cuba that showed moderate levels of resistance to temephos and primifos-methyl; and high values of resistance to chlorpyrifos. The bioassays showed that the resistance was caused by the mechanism of esterasas. ${ }^{29}$

Rodríguez et al., in 2006, evaluated in Santiago de Cuba the susceptibility to temephos, showing esterases as the mechanism of action; and in addition to this they demonstrated that the transmission of resistance can occur vertically from mothers to their offspring, similar to what Georghiou found in 1999 in Venezuelan populations. ${ }^{29}$

In two communities of the municipality of Guanabacoa in the city of the Habana, the susceptibility to insecticides of various kinds was measured, showing that one of the populations of larvae had high resistance to fention and temephos. However, the larvae were susceptible to organophosphate Malathion, chlorpyrifos, pirimiphos-methyl, fenitrothion and the carbamate propoxur. ${ }^{29}$ The other population showed resistance to fention, 
fenitrothion and temephos, associated to the mechanism of esterases elevation. ${ }^{15}$

In Trujillo, Peru around the year 2000, the temephos insecticide was used by the Ministry of Health with high frequency in the control programs of A. aegypti, an evaluation based on the WHO methodology in 4 strains belonging to the province Trujillo showed susceptibility of all strains. ${ }^{26}$

In two provinces of Peru, bioassays were conducted to know the resistance to insecticides and their associated mechanisms. The results showed that one strain is broadly resistant to the organophosphate chlorpyrifos and temephos and to the carbamate propoxur; while at fenithion and fenitrothion moderate resistance. And finally with complete susceptibility to Malathion; whose resistance mechanism is conditioned by esterases and GST. The other strain of larvae showed susceptibility to all organophosphates, except to fenithion, with moderate resistance to the mechanism of resistance to esterases, GST and modification of the enzyme acetylcholinesterase. ${ }^{30}$

Regarding the evaluated adults, one strain showed sensitivity to betacypermethrin and deltamethrin and the organophosphate chlorpyrifos; but resistant to DDT and labdacylthrin; and the other evaluated also showed resistance to DDT, pyrethroids, betacypermethrin, deltamethrin and lambdacihalothrin; however, it was only sensitive to chlorpyrifos. ${ }^{30}$

Organophosphates are known as insecticides with high resistance in almost all Latin America ${ }^{3}$; whose resistance is associated to the elevation of esterases. ${ }^{4}$

In multiple countries such as Brazil, Cuba, El Salvador, Argentina, Bolivia, Venezuela, Peru, Colombia ${ }^{3}$, and Panama, the use of temephos in the larval stage has been related to resistance. ${ }^{19}$

On the other hand, some insecticides such as organophosphates and deltamethrin, despite not having been used intensively in countries such as Colombia, Mexico, French Guiana, Peru, Cuba, Panama and Venezuela, also show resistance. ${ }^{19}$

Aedes aegypti, has shown resistance to organochlorines, organophosphates, pyrethroids and carbamates, that is, to all the insecticide groups currently available; the countries of Latin America that have reported these situations are Argentina, Brazil, Mexico, Salvador, Peru, Panama, Venezuela, Cuba, Puerto Rico and others from the Caribbean. ${ }^{3}$

\section{CONCLUSIONS}

Dengue is one of the most important re-emerging diseases in the world and generates more health expenses, due to the high rates of morbidity and mortality in Latin America.
Resistance to insecticides by Aedes aegypti is a reality that requires surveillance of the sensitivity of mosquito populations, the vast majority of the populations evaluated in Latin America show resistance to temephos.

Monitoring is proposed several times a year and in relation to seasonal changes, which it is known they can condition an increase in the mosquito population.

There are areas of opportunity for improvement that are still untackled, especially the discovery of new or complementary methods that allow vector control, in a chemical, physical or biological manner.

\section{REFERENCES}

1. Organización Mundial de la Salud. Temas de Salud: Dengue. [Document on the Internet]. 2019. [Updated 2019; cited February 24, 2019]. Available from: https://www.who.int/topics/dengue/es/

2. Vannice KS, Durbin A, Hombach J. Status of vaccine research and development of vaccines for dengue. Vaccine. 2016;34(26):2934-2938.

3. De La Cruz-Gallardo CM, Rodríguez-Pérez C, Ocaña-Zurita FJ. Susceptibilidad y resistencia a insecticida en mosquito transmisor del dengue. Sal. Tabasco. 2014;20(2):54-59.

4. Bisset Lazcano JA, Rodríguez MM, San Martín JL, Romero JE, Montoya R. Evaluación de la resistencia a insecticidas de una cepa de Aedes aegypti de El Salvador. Rev. Panam. Salud Pública. 2009;26(3): 229234.

5. Bharati M, Saha D. Multiple insecticide resistance mechanisms in primary dengue vector, Aedes aegypti (Linn.) from dengue endemic districts of sub-Himalayan West Bengal, India. PLoS ONE. 2018;13(9): e0203207.

6. Centro Nacional de Programas Preventivos y Control de Enfermedades. Monitoreo de Resistencia a Insecticidas (Adulticidas) Utilizados en el Programa Nacional de Control de Vectores en México. [Document on the Internet]. 2016. [Cited February 24, 2019]. Available from: http://www.cenaprece.salud.gob.mx/programas/interior/vectores/desca rgas/pdf/MonitoreoResistenciaInsecticidas2014.pdf

7. Marcombe S, Chonephetsarath S, Thammavong P, Brey PT. Alternative insecticides for larval control of the dengue vector Aedes aegypti in Lao PDR: insecticide resistance and semi-field trial study. Parasit. Vect. 2018;11(1):1-8.

8. Adriana E. Flores. Detección de resistencia a insecticidas en mosquitos con énfasis en Aedes aegypti. Artróp. Salud. 2014;1(2):21-36.

9. Organización Panamericana de la Salud. Guía de bolsillo: Diagnóstico y manejo clínico de casos de dengue. [Document on the Internet]. 2013. [Updated 2019; cited February 24, 2019]. Available from: https://www.who.int/denguecontrol/resources/guide diagnosis dengue les/

10. Moyes CL, Vontas J, Martins AJ, Ng LC, Koou SY, Dusfour I, et al. Contemporary status of insecticide resistance in the major Aedes vectors of arboviruses infecting humans. PLOS Negl. Trop. Dis. 2017;11(7):e0005625.

11. Shepard DS, Coudeville L, Halasa YA, Zambrano B, Dayan GH. Economic impact of dengue illness in the Americas. Am. J. Trop. Med. Hyg. 2011;84(2):200-207.

12. Organización Panamericana de la Salud. Descripción de la situación epidemiológica actual del dengue en las Américas. [Document on the Internet]. 2016. [Updated 2019; cited February 25, 2019]. Available from:

https://www.paho.org/hq/index.php?option=com_content\&view=articl 
e\&id=4494:2010-descripcion-situacion-epidemiologica-actual-dengue americas\&Itemid $=40370 \& l a n g=e s$

13. Prada MA. Un modelo de gestión ambiental para biorremediar suelos contaminados con 1,1,1- tricloro-2,2-bis (4-clorofenil)-etano (DDT) mediante un reactor de lecho estático. [Magisterial thesis]. Medellín: Universidad Nacional de Colombia; 2016.

14. Niang EHA, Bassene H, Fenollar F, Mediannikov O. Biological Control of Mosquito-Borne Diseases: The Potential of Wolbachia-Based Interventions in an IVM Framework. J. Trop. Med. 2018; 2018:1470459.

15. Rodríguez MM, Bisset JA, Fernández D, Pérez O. Resistencia a insecticidas en larvas y adultos de Aedes aegypti: prevalencia de la esterasa A4 asociada con la resistencia a temefos. Rev. Cubana Med. Trop. 2004;56(1):54-60.

16. Bellinato DF, Viana-Madeiros PF, Costa Araújo S, Martins AJ, Pereira Lima JB, Valle D. Resistance Status to the Insecticides Temephos, Deltametrin and Diflubenzuron in Brazilian Aedes aegypti Populations. BioMed Res. Int. 2016; 2016:8603263.

17. Moltini-Conclois I, Stalinski R, Tetreau G, Després L, Lambrechts L. Larval Exposure to the Bacterial Insecticide Bti Enhances Dengue Virus Suceptibility of adult Aedes aegypti mosquitoes. Insects. 2018;9(4):193201.

18. Darriet F, Duchon S, Hougard JM. Spinosad: a new larvicide against insecticide-resistant mosquito larvae. J. Am. Mosq. Cont. Assoc. 2005;21(4):495-496.

19. Conde M, Orjuela LI, Castellanos CA, Herrera-Varela M, Licastro S, Quiñones ML. Evaluación de la sensibilidad a insecticidas en poblaciones de Aedes aegypti (Diptera: Culicidae) del departamento de Caldas, Colombia, en 2007 y 2011. Biomed. 2015;35:43-52.

20. Seixas G, Grigoraki L, Weetman D, Vicente JL, Silva AC, Pinto J, et al. Insecticide resistance is mediated by multiple mechanisms in recently introduced Aedes aegypti from Madeira Island (Protugal). PLOS Negl. Trop. Dis. 2017;11(7):e0005799.

21. Li Y, Xu J, Zhong D, Zhang H, Yang W, Zhou G, et al. Evidence for multiple-insecticide resistance in urban Aedes albopictus populations in southern China. Parasit. Vect. 2018;11(1):4.

22. Organización Mundial de la Salud. Resistencia de los insectos a los insecticidas y la lucha contra los vectores de enfermedades. $13^{\circ}$ Informe del Comité de Expertos de la OMS en Insecticidas Ginebra. Serie de Informes Técnicos. 1959; 153:1-163. Available from: https://apps.who.int/iris/bitstream/handle/10665/37518/WHO_TRS_26 5_\%28part2\%29_spa.pdf?sequence $=2 \&$ isAllowed $=\mathrm{y}$

23. Brogdon WG, McAllister JC. Simplification of adult mosquito bioassays through use of time-mortality determinations in glass bottles. J. Am. Mosq. Cont. Assoc. 1998;14(2):159-64.

24. Correa-Morales F, Dzul-Manzanilla FA, Huerta H, González-Acosta C, Hernández-Herrera L, Torres Leyva J, et al. Monitoreo de la resistencia a insecticidas en el vector del Dengue, Chikungunya y Zika en Puerto Vallarta, Jalisco, México. Entomol. Mex. 2016; 3:735-745.

25. Bisset JA, Rodríguez MM, Molina D, Díaz C, Soca LA. Estereasas elevadas como mecanismo de resistencia a insecticidas organofosforados en cepas de Aedes aegypti. Rev. Cubana Med. Trop. 2001;53(1):37-43.

26. Chávez J, Córdova O, Vargas F. Niveles de susceptibilidad a temefos en el vector transmisor del dengue en Trujillo, Perú. An. Fac. Med. 2005;66(1):53-56.

27. Pereira Lima E, Santos Paiva MH, de Araújo AP, Gomes da Silva EV, da Silva UM, Nogueira Oliveira L, et al. Insecticide resistance in Aedes aegypti populations from Ceará, Brazil. Parasit. Vect. 2011;4(5):1-8.

28. Terán Zavala MC, Rodríguez Coto MM, Leyva YR, Bisset Lazcano JA. Evaluación de temefos y pyriproxifeno en Aedes aegypti (Diptera: Culicidae) de Guayaquil, Ecuador. Rev. Cubana Med. Trop. 2014;66(1):71-83.
29. Rodríguez MM, Bisset JA, Pérez O, Ramos F, Risco GE. Modo de herencia de la resistencia a temefos (abate) en Aedes aegypti (Diptera: Culicidae) de Cuba. Rev. Cubana Med. Trop. 2006;58(2):142-147.

30. Bisset JA, Rodríguez MM, Fernández D, Palomino M. Resistencia a insecticidas y mecanismos de resistencia en Aedes aegypti (Dipteria: Culicidae) de 2 provincias del Perú. Rev. Cubana Med. Trop. 2007;59(3):202-208. 